\title{
Istraživanje primjene korisničkih oznaka u predmetnom opisu građe: društveno označavanje
}

\section{Researching of Application of the User Bookmarks in Subject Cataloguing: Social Bookmarking}

\author{
Anida Ibričić \\ Sarajevo, Bosna i Hercegovina / Sarajevo, Bosnia and Herzegovina \\ anidaibricic@gmail.com
}

Informacije o članku / Article Info

Primljen / Received 12. 9. 2020.

Prihvaćen / Accepted 21. 10. 2020.

Dostupan online / Available online: 15. 12. 2020.

Ključne riječi / Keywords

predmetna obrada, korisničko označavanje, društveno označavanje

subject cataloguing, user bookmarking, social bookmarking

\section{Sažetak / Abstract}

Polazeći od potrebe iznalaženja rješenja poboljšanog pristupa građi u predmetnom katalogu, kao i poboljšanja predmetnog opisa, sprovedeno je istraživanje ispitivanja primjene korisničkih oznaka društvenog označavanja u okviru predmetne obrade građe. Cilj rada je komparativnom analizom korpusa ključnih riječi i korisničkih oznaka članaka triju časopisa Vjesnika bibliotekara Hrvatske (2019), Glasnika Narodne biblioteke Srbije $(2017,2018)$ i Bosniace (2019) ispitati primjenu korisničkih oznaka društvenog označavanja u predmetnoj obradi građe. U radu se naglašavaju prednosti primjene korisničkih oznaka u predmetnom opisu građe te se iznosi zaključak da korisničke oznake mogu unaprijediti i poboljšati pristup sadržaju u katalogu kroz korisničko označavanje, tj. društveno označavanje. Pretpostavka je da dobiveni rezultati nakon analize mogu biti indikativni za osmišljavanje strategije unapređenja predmetnog opisa i prilagođavanja bibliotečkog kataloga savremenom korisniku, na osnovu korisničkih oznaka dodijeljenih jezikom korisničke zajednice.

This research is done with the aim to find a solution on how to improve the accessibility of collections in catalogues and to improve subject cataloguing. The research is about questioning the application of user bookmarks of social marking within the subject cataloguing. The goal of this paper is to question the use of user tags in subject processing of the resources with comparative analysis of the bunch of keywords and user bookmarks of the articles in three journals including Vjesnik bibliotekara Hrvatske (2019), Glasnik Narodne biblioteke Srbije (2017, 2018) and Bosniaca (2019). This paper is highlighting the advantages of application user bookmarks in cataloguing and concluding that user bookmarks could improve and ameliorate access to a catalogue content through social bookmarking. The hypothesis is that the final result of analysis could be indicative of finding and designing a strategy that could improve subject cataloguing and adjustment of library catalogue to a modern user according to user tags which are assigned on common language.

\section{Uvod}

Ab Iove principium. - Početak je od Jupitera (tj. počnimo od najvažnijeg).

U bibliotečkom katalogu, de facto problem otežanog verbalnog predmetnog pristupa sadržaju do kojeg korisnik želi doći u potrazi za znanjem, oduvijek je postojao, kako u tradicionalnim, tako i u digitalnim bibliotekama i bazama podataka putem interneta $\mathrm{i}$ informacijsko-komunikacijskih tehnologija, kao novog načina "putovanja kroz sadržaje”. Taj problem, koji se najčešće ogleda u vidu predmetnih odrednica koje odstupaju od rječnika korisničkih riječi u okviru predmetne obrade građe, inicirao je provedbu istraživanja primjene korisničkih oznaka u predmetnom opisu građe. Cilj istraživanja je ispitati primjenu

\section{Introduction}

Ab Iove principium. - Everything begins with Jupiter (i.e. Start with the most important).

In the library catalogue, de facto problem of hampered verbal subject access to the content that the user wants to reach in search of knowledge, has always existed in both traditional and digital libraries and databases via the Internet and information and communication technologies, as a new way of "travelling through content". This problem, which is most often reflected in the form of subject headings that differ from the vocabulary of user words within the material subject cataloguing, initiated the implementation of research on the application of user bookmarks in the subject cataloguing of 
oznaka dodijeljenih od strane korisnika, to jest korisničkih oznaka društvenog označavanja u predmetnoj obradi, kroz statističku, značenjsku i lingvističku analizu. Sve to je ispitano komparativnom analizom ključnih riječi i korisničkih oznaka, članaka časopisa Vjesnika bibliotekara Hrvatske (2019), Glasnika Narodne biblioteke Srbije $(2017,2018)$ i Bosniace (2019), koji su poslužili kao primjeri ispitivanja primjene korisničkih oznaka društvenog označavanja u okviru predmetne obrade te građe.

U sklopu društvenog označavanja, oznake dodijeljene od strane korisnika predstavljaju korisničke oznake; predmetne odrednice predstavljaju oznake koje su rezultat predmetnog označavanja od strane stručnjaka. Mikačić (1996, 34-35) za definiciju predmetne odrednice navodi: predmetna odrednica jeste skup riječi, koje su pojmovne oznake, a koje u svojoj ukupnosti daju sažeti iskaz o predmetu sadržanom u pojedinom dokumentu. Na sličan način Lohmann $(2013,19)$ definiše korisničke oznake: korisničke oznake predstavljaju proizvoljne tekstualne oznake povezane s resursima. Kako korisničke oznake donose naznake novih elemenata opisa koji nisu prisutne $u$ tradicionalnom predmetnom pristupu obrade građe, za očekivati je da postoji kvantitativna, ali i kvalitativna razlika između korisničkih oznaka i ključnih riječi dodanih istoj građi. U okviru toga, u analizu krenulo se od sljedećih hipoteza:

H1: Postoji kvantitativna razlika između korisničkih oznaka i ključnih riječi iste građe.

Ova hipoteza ispitana je statističkom analizom prikupljenih korisničkih oznaka usporedno s ključnim riječima, kako bi se analizirala razlika na kvantitativnoj razini.

H2: Postoji kvalitativna razlika između korisničkih oznaka i ključnih riječi iste građe.

Hipoteza je ispitana lingvističkom i značenjskom analizom korisničkih oznaka kroz ispitivanje naznaka novih elemenata opisa koji donose oznake, a koje nisu prisutne u predmetnom opisu građe ključnim riječima; sve s ciljem poboljšanja kvalitete predmetnog opisa građe korisničkim oznakama.

Rezultati istraživanja primjene korisničkih oznaka u predmetnom opisu građe prikazani su kroz statističku, lingvističku i značenjsku razinu komparativne analize, koja je dala uvid u značaj društvenog označavanja.

\section{Društveno označavanje}

Korisničke oznake prepoznate su kao djelotvorne $\mathrm{u}$ organizaciji informacija zbog funkcionisanja korištenja kolektivne inteligencije, koja nastaje kao material. The aim of the research is to examine the application of bookmarks assigned by users, i.e. user bookmarks of social bookmarking in the subject cataloguing, through statistical, semantic, and linguistic analysis. All of this was examined by a comparative analysis of keywords and user bookmarks, journal articles in Vjesnik bibliotekara Hrvatske (Croatian Librarians Herald) (2019), Glasnik Narodne biblioteke Srbije (The Herald of the National Library of Serbia) $(2017,2018)$ and Bosniaca (2019), which served as examples of testing the usage of user bookmarks in social bookmarking within the subject cataloguing of that material.

As part of social bookmarking, user-assigned bookmarks represent user bookmarks, subject headings represent bookmarks that are the result of subject indexing by experts. Mikačić (1996, 34-35) for the definition of the subject heading states: subject heading is a set of words, which are term designations, and which in their entirety give a concise statement of the subject contained in a particular document. Similarly, Lohmann $(2013,19)$ defines user bookmarks: user bookmarks are arbitrary text tags associated with resources. Since user bookmarks bring indications of new description elements that are not present in the traditional subject approach to material cataloguing, it is to be expected that there is a quantitative but also a qualitative difference between user bookmarks and keywords added to the same material. Within this, the analysis started from the following hypotheses:

$\mathrm{H} 1$ : There is a quantitative difference between user bookmarks and keywords of the same material.

This hypothesis was tested by statistical analysis of collected user bookmarks in parallel with keywords, in order to analyze the difference at the quantitative level.

$\mathrm{H} 2$ : There is a qualitative difference between user bookmarks and keywords of the same material.

The hypothesis was tested by linguistic and semantic analysis of user bookmarks through the examination of indications of new elements of the description that bring the bookmarks, which are not present in the subject description of the material with the keywords, all with the aim of improving the quality of the subject description of the material by user bookmarks.

The results of the research on the application of user bookmarks in the subject description of the material are presented through the statistical, linguistic and semantic level of comparative analysis, which provided insight into the importance of social bookmarking. 
rezultat korisničkog sudjelovanja u dodjeljivanju oznaka koje će predmetno opisivati promatrani objekt građe, što predstavlja društveno označavanje. Ivanjko $(2015,50)$ za definiciju društvenog / korisničkog označavanja (engl. Tagging, Collaborative tagging, Social tagging / bookmarking) navodi da je to postupak organiziranja elektroničkih sadržaja, koji provodi više korisnika, na način da se ti sadržaji indeksiraju / kategoriziraju ad hoc dodijeljenim ključnim riječima. Naime, pod terminom društveno (engl. social) podrazumijeva se društvo kao skupina pojedinaca, aktivnih agenata, u konačnici korisnika koji učestvuju u označavanju sadržaja na internetu (Shirky Clay 2005, 183-209). Termin označavanje (engl. bookmarking, tagging) može se definisati kao dodjeljivanje / tagiranje korisničkih oznaka ili tagova (engl. bookmarks, tag) sadržaju koje čine ključne riječi, odnosno nekontrolisani termini koje korisnici dodjeljuju izvorima koje postavljaju ili koji su postavljeni na internetu od strane pojedinaca na nekoj od web stranica (Trant 2009). U vezi s tim, kolaborativno tagiranje (engl. Collaborative tagging) zapravo je rezultat zajedničkog označavanja korisnika i nastaje klasificiranjem sadržaja po određenim područjima (Golder i Huberman 2006), pri čemu se ukupan broj dodijeljenih korisničkih oznaka određenom sadržaju, proizašlih iz postupka društvenog označavanja, naziva folksonomija (engl. folksonomy) (Vander Wal 2007). Budući da folksonomija nastaje dodjeljivanjem tagova izvoru sadržaja na webu od strane korisnika kao aktera, ona kao takav način kategorizacije nema unaprijed osmišljenu koncepciju, već nastaje proizvoljnim i samoprocjenljivim djelovanjem korisnika u provedbi društvenog označavanja. To, dakako, nije slučaj primarno s bibliotekarima, stručnjacima koji u tradicionalnom modelu predmetnu obradu građe provode korištenjem pravila za kreiranje iskaza o dokumentu. Ono što se može navesti kao razlika između dodjeljivanja ključnih riječi od strane predmetnog stručnjaka i korisnika u procesu društvenog označavanja jeste to da uspješnost predmetne obrade građe zavisi od kvalitete obrade predmetnog stručnjaka, dok kod korisničkog označavanja uspješnost obrade spada na grupu korisnika. To znači da svaki korisnik može posebice dodijeliti željenu oznaku nekom izvoru, a kvantitet ponavljanja iste oznake od strane nekog trećeg korisnika pokazuje kvalitetu te iste oznake.

Za provedbu društvenog označavanja nužan i neminovan je odabir ciljanog alata koji omogućava provedbu društvenog označavanja. Neki od alata za društveno označavanje su: Pinboard, Digg, Diigo, Tagpacker, Pinterest, We Heart It, Plurk i mnogi

\section{Social bookmarking}

User bookmarks have been recognized as effective in organizing information due to the functioning of the use of collective intelligence, which arises as a result of user participation in the assignment of bookmarks that will objectively describe the observed material object, which represents social bookmarking. Ivanjko $(2015,50)$ for definition of social/user bookmarking (or Tagging, Collaborative tagging, Social tagging/bookmarking) states that it is a process of organizing electronic content, which is carried out by several users in a way that these contents are indexed / categorized ad hoc to assigned keywords. In fact, under the term social, society is understood as a group of individuals, active agents, ultimately, the users who participate in the bookmarking of content on the Internet (Shirky Clay 2005, 183-209). Term bookmarking (or tagging) can be defined as assigning / tagging user bookmarks or tags to the content that consists of keywords, i.e. uncontrolled terms that users assign to sources that they post or that are posted on the Internet by individuals on one of the websites (Trant 2009). On this matter, collaborative tagging is actually the result of common user bookmarking that results from classifying content by specific areas (Golder and Huberman 2006), where the total number of assigned user bookmarks to a particular content, originated from the social bookmarks process, is called folksonomy (Vander Wal 2007). Because folksonomy is created by assigning bookmarks to a source of content on the web by users as participants, and as such way of categorization, it does not have a preconceived concept, but arises from the arbitrary and selfassessing actions of users in the implementation of social bookmarking. This, of course, is not the case primarily with librarians, experts who in the traditional model carry out the subject cataloguing of material using the rules for creating statements about the document. What can be stated as the difference between the assignment of keywords by the subject expert and the user in the social bookmarking process, is that the success of the subject cataloguing of the material depends on the quality of the cataloguing of the subject expert, while in the case of user bookmarking the success of the cataloguing belongs to the group of users. This means that each user can individually assign the desired bookmark to a source, and the quantity of repetition of the same bookmark by a third user shows the quality of that same bookmark. 
drugi. Diigo alat je jedan od najpopularnijih alata za društveno označavanje, a ujedno je korišten i za potrebe ovoga istraživanja, kao centralizirano mjesto za provedbu korisničkog / društvenog označavanja.

\section{Komparativna analiza časopisa}

Metodom online nabave iz mnoštva (engl. crowdsourcing) prikupljen je korpus korisničkih oznaka putem Diigo alata za društveno označavanje. Korisnici su po vlastitom mišljenju dodijelili svakom članku časopisa Bosniace (2019), Vjesnika bibliotekara Hrvatske (2019) i Glasnika narodne biblioteke Srbije $(2017,2018)$ oznake koje su oni prepoznali kao djelotvorne $u$ organizaciji informacija i komplementiranju predmetne obrade građe. Pristup Diigo grupi "Folksonomija", odnosno cjelokupnom korpusu članaka časopisa i dodijeljenih korisničkih oznaka, kao i profilima korisnika dodjeljivača, omogućen je putem linka: https://groups.diigo.com/group/ folksonomija. In medias res, sprovedenom analizom korpusa korisničkih oznaka usporedno s ključnim riječima, kroz tri faze istraživanja uz ispitivanje postavljenih hipoteza, došlo se do sljedećih rezultata:

\section{Statistička analiza}

Statistička analiza odnosila se na ispitivanje kvantitativne razlike između omjera korpusa ključnih riječi i korisničkih oznaka triju časopisa: Bosniace (2019), Vjesnika bibliotekara Hrvatske (2019) i Glasnika narodne biblioteke Srbije (2017, 2018). Putem Diigo alata za društveno označavanje, ukupno je dodijeljeno 2458 korisničkih oznaka na uzorku od po deset članaka za sva tri gore spomenuta časopisa, od kojih je 505 jedinstvenih / dodanih korisničkih oznaka (Grafikon 1), dok ukupan broj ključnih riječi koje se nalaze uz članke časopisa iznosi 131.

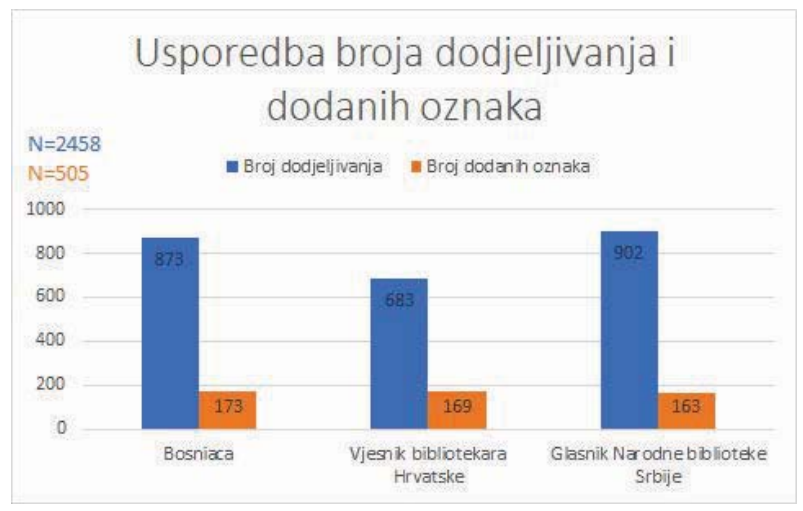

Grafikon 1. Usporedba broja dodjeljivanja i dodanih oznaka za sva tri časopisa

Kao što vidimo, od ukupnog broja od 2458 dodijeljenih korisničkih oznaka, 873 oznake su dodijeljene Bosniaci (2019), 683 Vjesniku bibliotekara Hrvatske
The implementation of social bookmarking is necessary and inevitable to choose a targeted tool that enables the implementation of social bookmarking. Some of the social bookmarking tools are: Pinboard, Digg, Diigo, Tagpacker, Pinterest, We Heart It, Plurk and many others. Diigo tool is one of the most popular tools for social bookmarking, which was also used for the purposes of this research as a centralized place for the implementation of user / social bookmarking.

\section{Comparative journal analysis}

By the method of online crowdsourcing a corpus of user bookmarks was collected through the Diigo social bookmarking tool. Users have assigned in their own opinion to each journal article in Bosniaca (2019), Vjesnik bibliotekara Hrvatske (Croatian Librarians Herald) (2019) and Glasnik Narodne biblioteke Srbije (The Herald of the National Library of Serbia) $(2017,2018)$ bookmarks which they recognized as effective in organizing information and complementing the material subject cataloguing. Access to Diigo group "Folksonomy", that is, the entire corpus of journal articles and assigned user bookmarks, as well as to the profiles of the assignor users, is enabled via the link: https://groups.diigo. com/group/folksonomija. In medias res, the implemented analysis of the corpus of user bookmarks in parallel with the keywords, through three phases of research with the examination of the hypotheses, led to the following results.

\section{Statistical analysis}

Statistical analysis related to the examination of the quantitative difference between the ratio of the corpus of keywords and user bookmarks of three journals: Bosniaca (2019), Vjesnik bibliotekara Hrvatske (Croatian Librarians Herald) (2019) and Glasnik Narodne biblioteke Srbije (The Herald of the National Library of Serbia) $(2017,2018)$. Through the Diigo social bookmarking tool, a total of 2458 user bookmarks were assigned to a sample of ten articles for all three of the abovementioned journals, of which 505 were unique / added user bookmarks (Chart 1), while the total number of keywords that accompanied journal articles is 131 . 
(2019) i 902 oznake Glasniku Narodne biblioteke Srbije $(2017,2018)$, od kojih je broj dodanih oznaka za prvi časopis 173 , za drugi časopis 169 i za treći časopis 163; što zbirno iznosi 505 jedinstvenih, dodanih korisničkih oznaka za sva tri časopisa.

Omjeri ključnih riječi i korisničkih oznaka, s obzirom na spomenutu kvantitativnu metodu promatranja u ovome istraživanju zasebno, za Bosniacu (2019) su 49 : 173, za Vjesnik bibliotekara Hrvatske (2019) 41 : 169, a za Glasnik Narodne biblioteke Srbije $(2017,2018) 41: 163$.

Ovi statistički pokazatelji omjera ključnih riječi naspram korisničkih oznaka potvrđuju prvu hipotezu statističke analize za sva tri časopisa: h1. ključnih riječi će biti manje u odnosu na korisničke oznake. Kao što vidimo iz prikaza omjera oznaka časopisa, od ukupno 222 oznake za Bosniacu (2019), 78\% je više korisničkih oznaka u odnosu na ključne riječi, a od ukupno 210 oznaka za Vjesnik bibliotekara Hrvatske (2019) 80\%. Za Glasnik Narodne biblioteke Srbije $(2017,2018)$ relativni pokazatelj razlike korisničkih oznaka naspram ključnih riječi iznosi $78 \%$ u korist korisničkih oznaka, što je u globalu za sva tri časopisa od ukupno 636 oznaka, u prosjeku $79 \%$ više korisničkih oznaka.

Analizom frekvencije pojavljivanja pojedinih riječi kao korisničkih oznaka za članke sva tri časopisa, $\mathrm{s}$ brojem pojavljivanja korisničkih oznaka u intervalima: korisnička se oznaka pojavljuje jednom, od 2 do 5 puta, te od 6 do 13 puta ponavljanja, odnosno dodjeljivanja iste oznake od strane korisnika, dobijen je prikaz frekvencije ponavljanja korisničkih oznaka zasebno za sva tri časopisa (Grafikon 2).

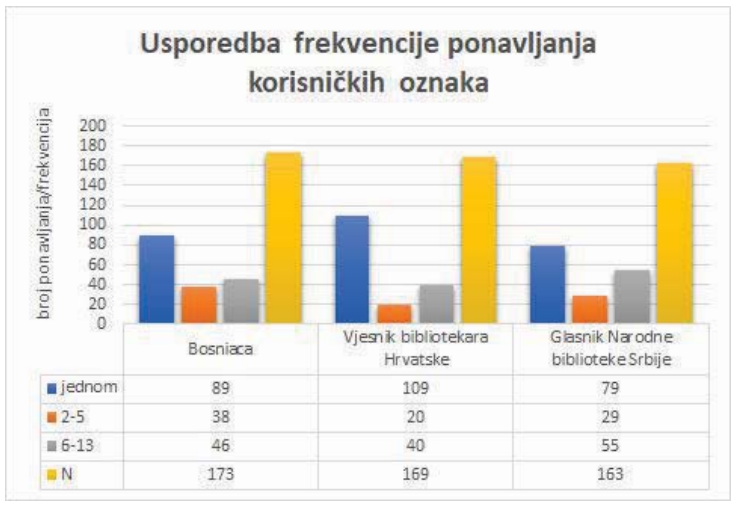

Grafikon 2. Usporedba frekvencije ponavljanja korisničkih oznaka za sva tri časopisa

Sakupljanjem svih korisničkih oznaka sa sveukupnim zasebnim zbirovima na nivou članaka u intervalima pojavljivanja korisničkih oznaka koje se ponavljaju, sumirano i s korisničkim oznakama koje se pojavljuju jedanput, vidljivo je da postoji razlika

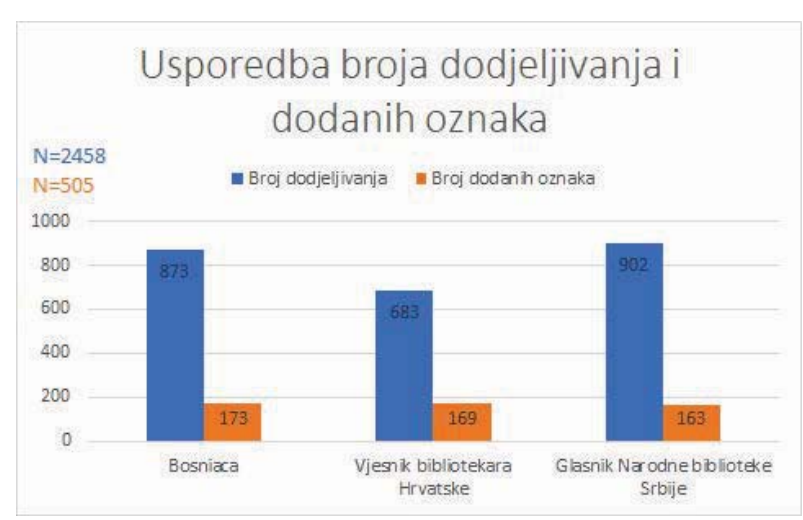

Chart 1. Comparison of the number of assignments and added bookmarks for 30 articles from three journals

As we can see, out of a total of 2458 assigned user bookmarks, 873 bookmarks have been assigned to Bosniaca (2019), 683 to Vjesnik bibliotekara Hrvatske (Croatian Librarians Herald) (2019) and 902 bookmarks to Glasnik Narodne biblioteke Srbi$j e$ (The Herald of the National Library of Serbia) $(2017,2018)$, of which the number of bookmarks added for the first journal is 173 , for the second journal 169 and for the third journal 163, which is total of 505 unique, added user bookmarks for all three journals.

The ratios of keywords and user bookmarks, given the mentioned quantitative method of observation in this study separately, for Bosniaca (2019) are 49 : 173, for Vjesnik bibliotekara Hrvatske (Croatian Librarians Herald) (2019) 41 : 169, and for Glasnik Narodne biblioteke Srbije (The Herald of the National Library of Serbia) $(2017,2018) 41: 163$.

These statistical ratio indicators of keywords to user bookmarks confirm the first hypothesis of statistical analysis for all three journals h1: there will be less keywords than user bookmarks. As we can see from the display of journal bookmark ratios, out of a total of 222 bookmarks for Bosniaca (2019), 78\% has more user bookmarks than keywords, and out of a total of 210 bookmarks for Vjesnik bibliotekara Hrvatske (Croatian Librarians Herald) (2019) it is $80 \%$. For Glasnik Narodne biblioteke Srbije (The Herald of the National Library of Serbia) (2017, 2018), the relative indicator of the difference between user bookmarks versus keywords is $78 \%$ in favour of user bookmarks, which is in general for all three journals out of a total of 636 bookmarks, on average $79 \%$ more user bookmarks.

By analyzing the frequency of occurrence of individual words as user bookmarks for articles in all three journals with the number of occurrences of user bookmarks in intervals: the user bookmark appears once, from 2 to 5 times, and from 6 to 13 re- 
u frekvenciji ponavljanja korisničkih oznaka za sva tri časopisa.

Naime, od ukupnog broja korisničkih oznaka 173 za Bosniacu (2019), frekvencija ponavljanja korisničkih oznaka je na relaciji $51 \%$ oznaka koje se samo jednom pojavljuju naspram $49 \%$ oznaka koje se ponavljaju više puta. Kao što vidimo, procentualno postoji zanemarljivo manji broj oznaka niske frekvencije (veliki broj oznaka koje su dodane samo jednom) u odnosu na broj velike frekvencije (mali broj oznaka koje su često dodane).

Signifikantno je s časopisom Vjesnik bibliotekara Hrvatske (2019), pri čemu od ukupno 169 korisničkih oznaka niska frekvencija naspram velike frekvencije ima sljedeću relaciju: $64 \%$ naspram 36\%, što predstavlja približno udvostručenje korisničkih oznaka koje se ponavljaju naspram korisničkih oznaka koje se pojavljuju jedanput.

U odnosu na prethodna dva časopisa, korisničke oznake Glasnika Narodne biblioteke Srbije (2017, 2018) zauzimaju relaciju $48 \%$ : 52\%, u kojoj dominira velika frekvencija naspram niske frekvencije pojavljivanja korisničkih oznaka. Prema tome, za ovaj časopis nije potvrđena hipoteza: h2. frekvencija broja dodijeljenih identičnih korisničkih oznaka od strane korisnika dodjeljivača je niska. Za časopise Bosniaca (2019) i Vjesnik bibliotekara Hrvatske (2019) potvrđena je prethodna hipoteza, koja je ujedno i indikator na primjenu korisničkih oznaka u predmetnom opisu građe zbog povećanja korpusa oznaka koje opisuju sadržaj.

U konačnici, provođenjem statističke analize na razini omjera ključnih riječi i korisničkih oznaka, kao i frekvencije ponavljanja korisničkih oznaka, u cilju prikaza razlike na spomenutim kvantitativnim razinama, hipoteza h1: postoji kvantitativna razlika između korisničkih oznaka i ključnih riječi iste građe, potvrđena je za sva tri časopisa. Taj kvantitet prevashodno se ogleda u gotovo učetverostručenom broju korisničkih oznaka nasuprot broju ključnih riječi, koje su s korisničkog aspekta samoprocijenjenog opisivanja iscrpne. Činjenica je da je prisutni broj korisničkih oznaka u velikoj mjeri veći od broja ključnih riječi te da iste te oznake ne povećavaju samo broj frekvencije već postojećih oznaka nego dakako povećaju i korpus korisničkog rječnika, čija bi primjena u predmetnom opisu građe imala za cilj omogućiti lakši i brži pronalazak iste te građe.

\section{Lingvistička analiza}

Ova se analiza odnosila na formalnu analizu vezanu uz gramatička obilježja korisničkih oznaka, kako bi currences, that is, the assignment of the same bookmark by the user, the frequency of user bookmark recurrence was obtained separately for all three journals (Chart 2).

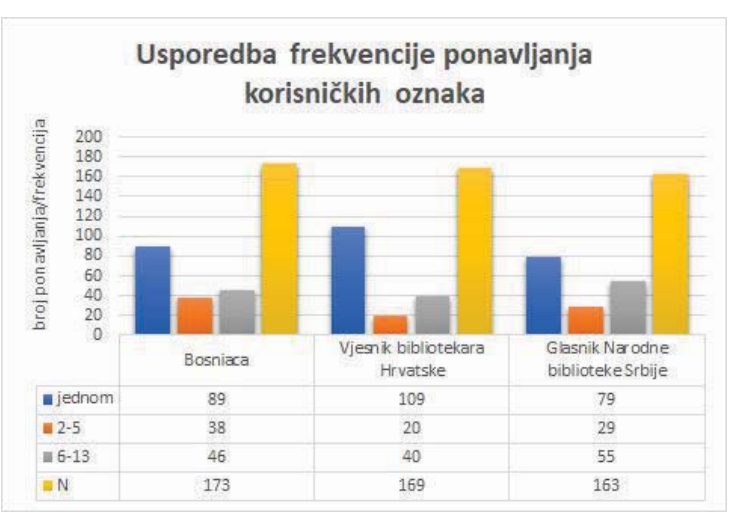

Chart 2. Comparison of user bookmarking recurrence frequency for all three journals

By collecting all user bookmarks with total separate sums at the article level at user bookmarks occurrence intervals which recur, summarized also with user bookmarks which are repeated once, it is evident that there is a difference in the frequency of reoccurrence of user bookmarks for all three journals.

In fact, out of the total number of user bookmarks of 173 for Bosniaca (2019), the frequency of reoccurrence of user bookmarks is on the relation $51 \%$ of bookmarks that appear only once versus $49 \%$ of bookmarks which are repeated several times. As we can see, there is a negligible percentage of low frequency bookmarks (a large number of bookmarks added only once) compared to a high frequency number (a small number of bookmarks that are added often).

The journal Vjesnik bibliotekara Hrvatske (Croatian Librarians Herald) (2019) is significant that out of a total of 169 user bookmarks, the low frequency versus the high frequency has the following relation: $64 \%$ vs. $36 \%$, which represents an approximate duplication of user bookmarks that are repeated versus user bookmarks that appear once.

Compared to the previous two journals, user bookmarks for Glasnik Narodne biblioteke Srbije (The Herald of the National Library of Serbia) (2017, 2018) take the following relation: $48 \%: 52 \%$, which is dominated by a high frequency versus a low frequency of occurrence of user bookmarks. Therefore, the hypothesis for this journal h2: the frequency of the number of identical user bookmarks assigned by the assignor user is low, has not been confirmed. For journals Bosniaca (2019) and Vjesnik bibliotekara Hrvatske (Croatian Librarians Herald) (2019) the previous hypothesis was confirmed, which is also an 
se dobio uvid u kvalitet oznaka koje su korisnici dodali člancima časopisa.

Analiza je rađena prema modelu analize doktorske disertacije Pristup analizi $i$ primjeni korisničkog označivanja u predmetnom opisu baštinske građe (Ivanjko 2015, 124, prema modelu Špiranec i Ivanjko 2012, 68), koji je istu analizu uradio u svom radu na osnovu kategorizacije korisničkih oznaka predloženih u radu Heckner, Mühlbacher i Wolf (2008, citirano prema Ivanjko 2015, 124), a koju su Špiranec i Ivanjko (2012, citirano prema Ivanjko 2015, 124) prilagodili za potrebe vlastitih istraživanja korpusa oznaka (Slika 1):

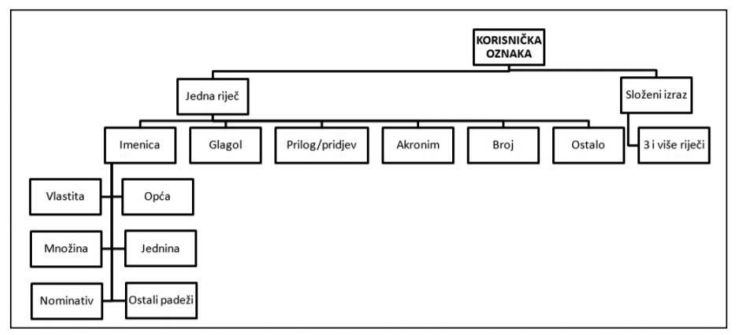

Slika 1. Kategorije lingvističke analize

Prema predstavljenoj kategorizaciji korisničkih oznaka, najprije je izvršena analiza korisničkih oznaka usporedno za sva tri časopisa prema broju riječi od kojih se sastoje korisničke oznake (Grafikon 3), pri čemu su korisničke oznake diferencirane u grupe: jedna riječ, složeni izraz i 3 i više riječi. Analiza je provedena na korpusu od 505 dodanih korisničkih oznaka, od kojih su 173 oznake bh. časopisa, 169 oznake hrv. časopisa i 164 oznake srp. časopisa.

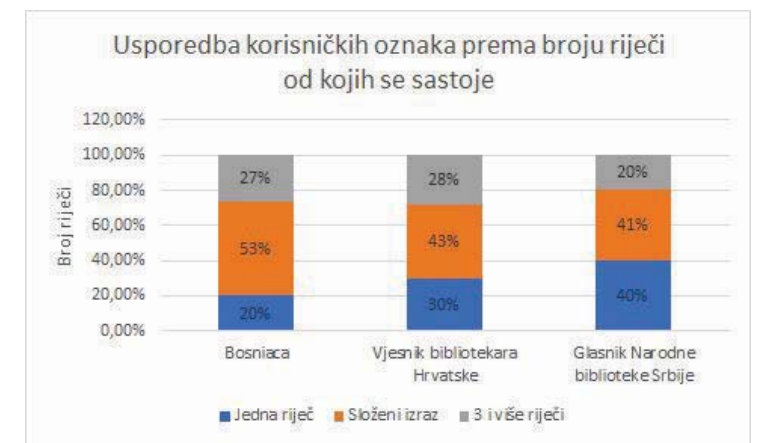

Grafikon 3. Usporedna analiza korisničkih oznaka časopisa prema broju riječi od kojih se sastoje

Kao što je vidljivo iz podataka predstavljenih u procentima, objedinjeno za sva tri časopisa, najveći broj korisničkih oznaka sastojao se od složenih izraza: 53\% Bosniaca (2019), 43\% Vjesnik bibliotekara Hrvatske (2019) i 41\% Glasnik Narodne biblioteke Srbije $(2017,2018)$; nešto manje oznaka se sastojalo od jedne riječi: $30 \%$ hrv. časopis, $40 \%$ srp. časopis, dok je bh. časopis zauzeo udjelno najmanje indicator of the use of user bookmarks in the subject cataloguing of the material due to the increase in the corpus of bookmarks that describe the content.

Ultimately, by conducting statistical analysis at the level of the ratio of keywords and user bookmarks, as well as user bookmark recurrence frequencies, in order to show the difference at the mentioned quantitative levels, the hypothesis h1: there is a quantitative difference between user bookmarks and keywords of the same material, has been confirmed for all three journals. This quantity is primarily reflected in the almost quadrupled number of user bookmarks versus the number of keywords, which are detailed from the user aspect of self-assessment. The fact is that the number of present user bookmarks is largely higher than the number of keywords, and that the same bookmarks increase not only the number of frequencies but the existing bookmarks, rather than increasing the corpus of the user dictionary, whose application in the subject cataloguing of the material would aim to enable easier and faster finding of the same material.

\section{Linguistic analysis}

This analysis has referred to a formal analysis related to the grammatical features of user bookmarks, in order to gain insight into the quality of bookmarks that users added to journal articles.

The analysis was done according to the doctoral dissertation analysis model Pristup analizi i primjeni korisničkog označivanja u predmetnom opisu baštinske građe (Analysis and implementation of folksonomies in subject indexing of heritage materials) (Ivanjko 2015, 124, according to the model Špiranec and Ivanjko 2012, 68), who did the same analysis in his paper based on the categorization of user bookmarks proposed in the paper Heckner, Mühlbacher and Wolf (2008, cited according Ivanjko 2015, 124), and which are Špiranec and Ivanjko (2012, cited according Ivanjko 2015, 124) adapted for the purposes of their own bookmark corpus research (Figure 1):

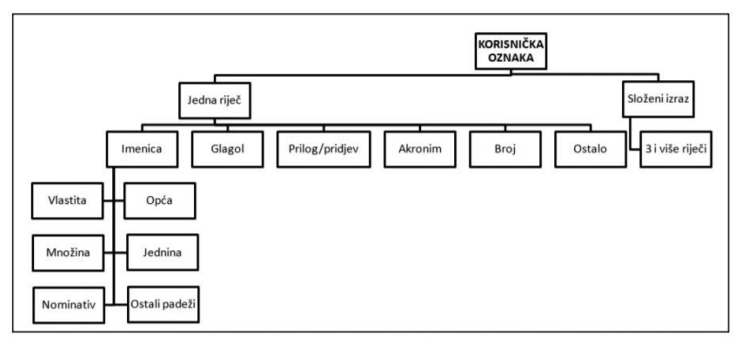

Figure 1. Categories of linguistic analysis 
procenata, 20\% oznaka od jedne riječi. Približno podjednake udjele iz grupe oznaka od 3 i više riječi su imali bh. i hrv. časopisi od 27 i $28 \%$, dok je srp. časopis imao najmanji udio od $20 \%$ riječi iz spomenute grupe korisničkih oznaka.

Sljedeća provedena analiza je analiza korisničkih oznaka prema vrsti riječi. Analiza je izvršena grupisanjem korisničkih oznaka prema kategorizaciji korisničkih oznaka, zasebno s ukupnim brojem korisničkih oznaka za sva tri časopisa pojedinačno, prema sljedećim vrstama riječi: imenice, glagoli, pridjevi, akronimi, brojevi i ostalo (Grafikon 4).

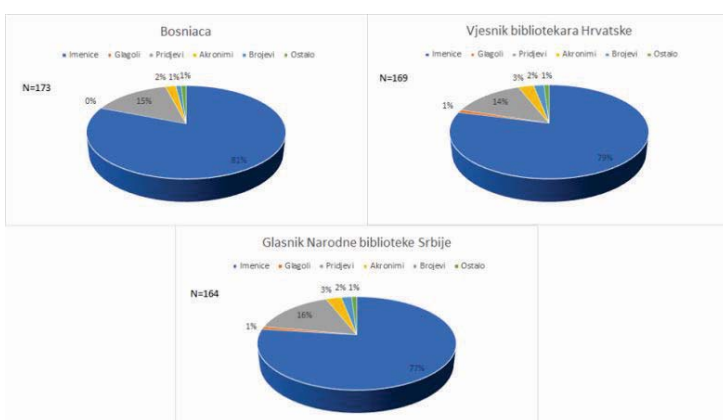

Grafikon 4. Analiza korisničkih oznaka časopisa prema vrsti riječi

Na osnovu podataka sa slike, očigledno je da velika većina riječi pripada imenicama za sva tri časopisa: 81\% za Bosniacu (2019), 79\% za Vjesnik bibliotekara Hrvatske (2019) i 77\% za Glasnik Narodne biblioteke Srbije (2017, 2018). Procentualno manji dio u odnosu na imenice zauzimaju pridjevi s približno $15 \%$ za sva tri časopisa. Ostale vrste riječi evidentno su prisutne u najmanjem broju od 3 i manje od $3 \%$ riječi.

Prema udjelno najvećem broju riječi koje pripadaju imenicama, ali ponajprije prema postavljenoj kategorizaciji analize, izvršena je i posljednja lingvistička analiza prema vrsti (Grafikon 5), padežu (Grafikon 6) i broju imenica (Grafikon 7) za sve časopise.

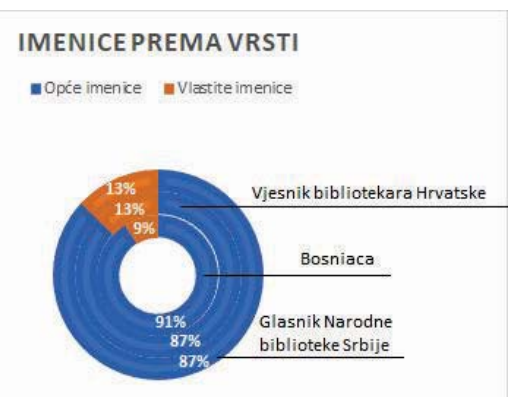

Grafikon 5.: Imenice prema vrsti
According to the presented categorization of user bookmarks, the analysis of user bookmarks was performed first in parallel for all three journals according to the number of words that make up user bookmarks (Chart 3), where user bookmarks are differentiated into groups: one word, compound expression, and 3 or more words. The analysis was performed on a corpus of 505 added user bookmarks, of which 173 are bookmarks of BH journals, 169 bookmarks are Croatian journals and 164 bookmarks are Serbian journals.

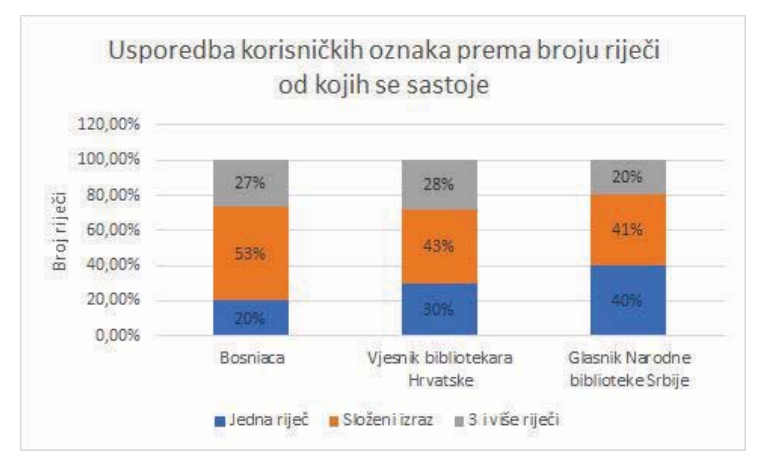

Chart 3. Comparative analysis of journal user bookmarks according to the number of words they consist of

As can be seen from the presented percentage data, combined for all three journals, the largest number of user bookmarks consisted of complex expressions: 53\% Bosniaca (2019), 43\% Vjesnik bibliotekara Hrvatske (Croatian Librarians Herald) (2019) and 41\% Glasnik Narodne biblioteke Srbije (The Herald of the National Library of Serbia) (2017, 2018), a slightly less bookmarks consisted of a single word $30 \%$ for Croatian journal, $40 \%$ for Serbian journal, while the BH journal took the lowest percentage share, $20 \%$ of one-word bookmark. Approximately equal shares from the group of bookmarks from 3 and more words had $\mathrm{BH}$ and Croatian journals - from 27 and 28\%, while Serbian journal had a minimum share of $20 \%$ of the words from mentioned group of user bookmarks.

The next performed analysis is the analysis of user bookmarks by word class. The analysis was performed by grouping user bookmarks according to the categorization of user bookmarks, separately with the total number of user bookmarks for all three journals individually, according to the following classes of words: nouns, verbs, adjectives, acronyms, numbers and rest (Chart 4). 
Kao što vidimo, većina imenica za sva tri časopisa pripada općim imenicama, s po $87 \%$ za hrv. i srp. časopis i $91 \%$ za bh. časopis, dok od ukupnog korpusa, $9 \%$ imenica bh. časopisa i po $13 \%$ ostalih dvaju časopisa pripadaju vlastitim imenicama.

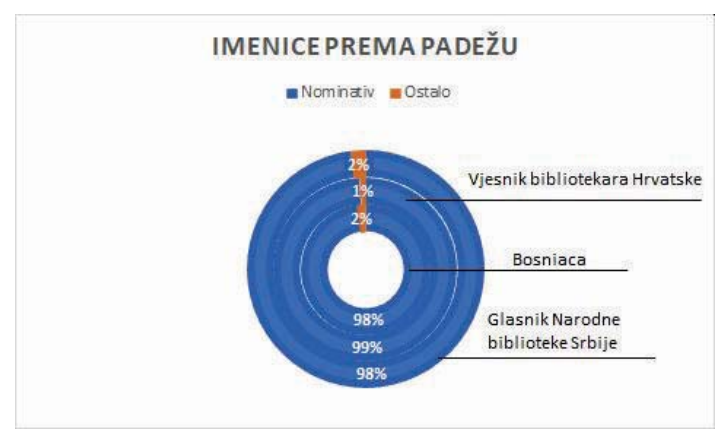

Grafikon 6. Imenice prema padežu

Prema padežu, imenice za sva tri časopisa zauzimaju približno isti većinski procenat imenica u nominativu od po $98 \%$ za bh. i srp. časopis i $99 \%$ za hrv. časopis, dok su imenice u ostalim padežima prisutne u izrazito malom broju od $2 \%$ i $1 \%$ po prethodno navedenom redoslijedu časopisa.

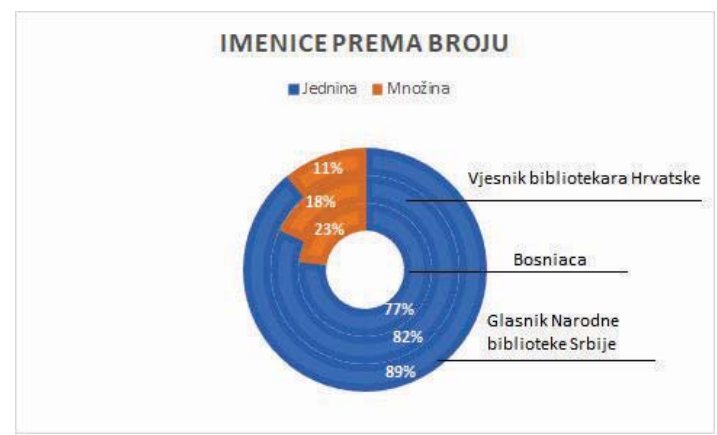

Grafikon 7. Imenice prema broju

Imenice prema broju zauzimaju većinski udjel za sva tri časopisa imenicama u jednini od $77 \%$ za Bosniacu (2019), 82\% za Vjesnik bibliotekara Hrvatske (2019) i 89\% za Glasnik Narodne biblioteke Srbije $(2017,2018)$, dok su ostale imenice prisutne u množini s manjim udjelom od $23 \%$ za bh. časopis, $18 \%$ za hrv. časopis i $11 \%$ za srp. časopis.

Nakon provedene analize, $\mathrm{s}$ rezultatima od udjelno najvećeg broja složenih izraza korisničkih oznaka koje pripadaju općim imenicama u jednini i nominativu, zaključeno je da su u lingvističkoj analizi ključnih riječi također najviše zastupljene opće imenice u složenim izrazima u jednini i nominativu, što ne potvrđuje kvalitativne razlike između promatranih oznaka. S druge strane, broj dodanih oznaka pokazuje prisutnost oznaka koje nisu prisutne $u$ predmetnom opisu ključnim riječima. Prema tome, prisutnost novih elemenata oznaka, proizašlih od

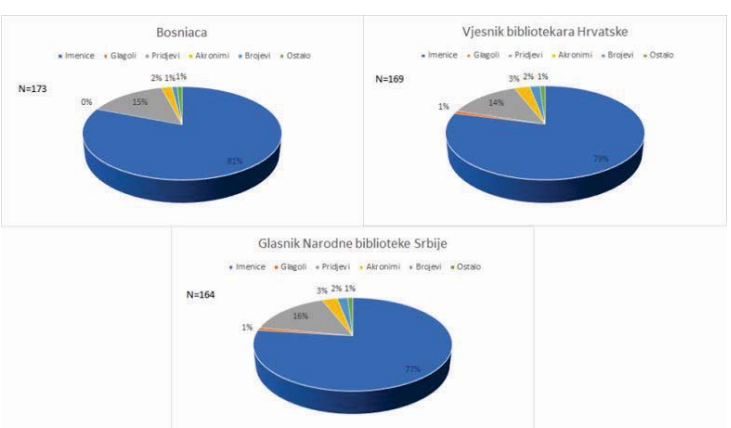

Chart 4. Analysis of journal user bookmarks by word class

Based on the data from the picture, it is obvious that the large majority of words belong to nouns for all three journals: $81 \%$ for Bosniaca (2019), 79\% for Vjesnik bibliotekara Hrvatske (Croatian Librarians Herald) (2019) and 77\% for Glasnik Narodne biblioteke Srbije (The Herald of the National Library of Serbia) $(2017,2018)$. In percentage terms, a smaller part in relation to nouns is occupied by adjectives with approximately $15 \%$ for all three journals. Other types of words are evidently present in the smallest number of 3 and less than $3 \%$ of words.

According to the share of highest number of words which are belonging to nouns, but primarily according to the fixed categorization of the analysis, the last analysis of linguistic analysis was also performed by class (Chart 5), grammatical case (Chart 6) and the number of nouns (Chart 7) for all journals.

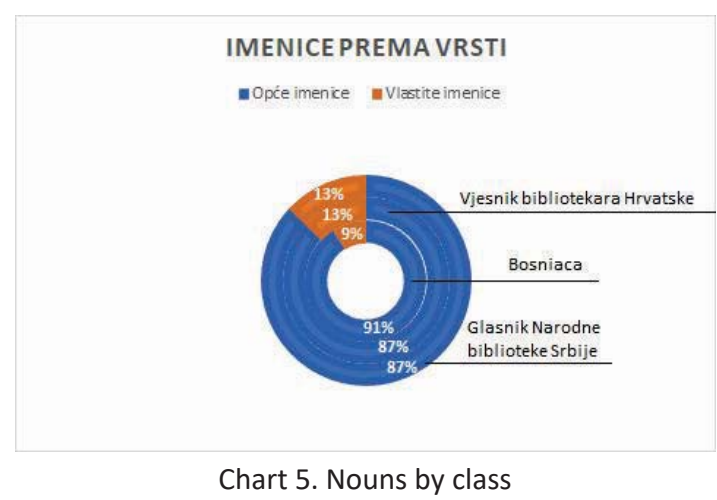

As we can see, most nouns for all three journals belong to common nouns, with $87 \%$ for Croatian and Serbian journal and $91 \%$ for $\mathrm{BH}$ journal, while from the total corpus, $9 \%$ nouns of $\mathrm{BH}$ journal and $13 \%$ of the other two journals belong to the proper nouns. 
strane korisnika dodjeljivača istih oznaka, umnogome govori o važnoj ulozi folksonomija u organizaciji i pretraživanju informacija, čime je potvrđena hipoteza koja se odnosi na lingvističku analizu h2: postoji kvalitativna razlika između korisničkih oznaka i ključnih riječi iste građe.

\section{Značenjska analiza}

Značenjska analiza se odnosila na sadržajnu analizu vezanu za značenje korisničkih oznaka, koja je izvršena s ciljem uvida u kvalitet oznaka koje su korisnici dodali člancima časopisa.

Ivanjko $(2015,128-130)$ za istoimenu analizu koristi model autora Klenczonija i Rygiela (2004, 4261, citirano prema Ivanjko 2015, 129), koji se prevashodno odnose na značenjsku analizu vizualne građe, koje je Ivanjko objedinio u tabelu (Slika 2), a koju smo za potrebe ovoga rada prilagodili analizi korisničkih oznaka časopisa.

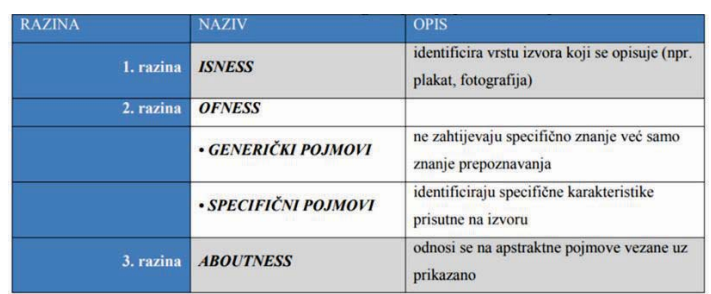

Slika 2. Razine značenjske analize korisničkih oznaka (Ivanjko 2015, 130)

Prva razina - isness - identificira vrstu izvora koji se opisuje; druga - ofness - odnosi se na identificiranje pojmova vezanih uz resurs, detaljnije razrađuje razinu ofness na generičke pojmove (koji ne zahtijevaju specifično znanje, već samo znanje prepoznavanja) te specifične pojmove (koji identificiraju specifične karakteristike prisutne na izvoru), dok se treća razina - aboutness - odnosi na apstrakthe pojmove vezane uz prikazano.

Prema postavljenom modelu, provedena je analiza značenja razina korisničkih oznaka članaka za sva tri časopisa koji su predmet ovog istraživanja (Tabela 1).

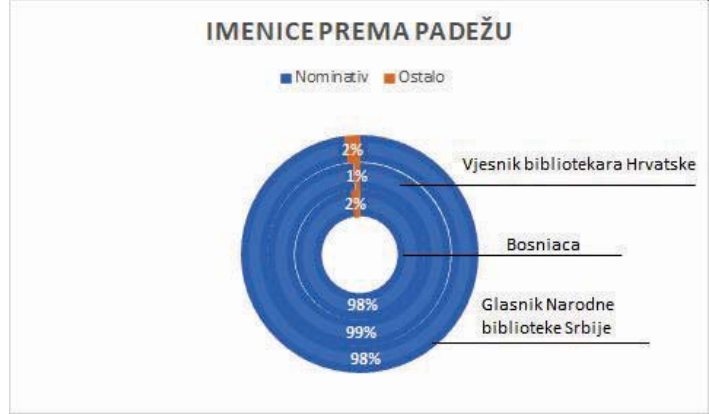

Chart 6. Nouns according to grammatical cases

According to the grammatical case, nouns for all three journals cover approximately the same majority percentage of nouns in the nominative case of the $98 \%$ for BH and Serbian journal and $99 \%$ for Croatian journal, while nouns in other grammatical cases are present in a very small number of $2 \%$ and $1 \%$ in the aforementioned order of the journal.

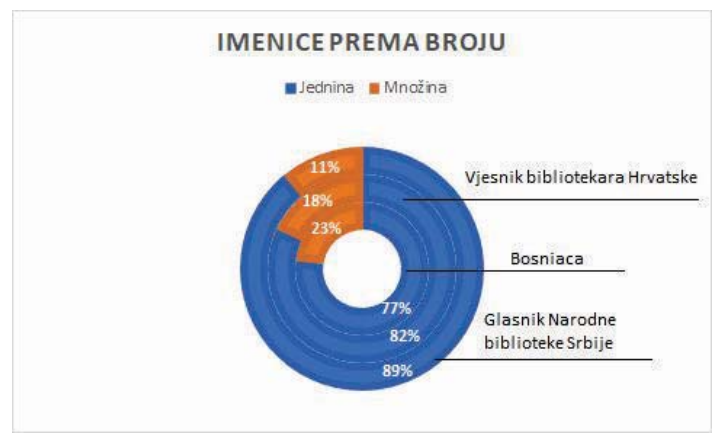

Chart 7. Nouns by number

Nouns by number cover the majority share for all three journals by singular nouns of $77 \%$ for Bosniaca (2019), 82\% for Vjesnik bibliotekara Hrvatske (Croatian Librarians Herald) (2019) and 89\% for Glasnik Narodne biblioteke Srbije (The Herald of the National Library of Serbia) $(2017,2018)$, while other nouns are present in the plural with a smaller share of $23 \%$ for BH journal, $18 \%$ for Croatian journal and $11 \%$ for Serbian journal.

After the analysis, with the results of the share of the highest number of complex expressions of user bookmarks that belong to common nouns in the singular and nominative case, it was concluded that in the linguistic analysis of keywords the most

Tabela 1. Rezultati analize značenja razina korisničkih oznaka časopisa

\begin{tabular}{|c|c|c|c|c|c|c|}
\hline Naziv časopisa & $\begin{array}{c}\text { Broj } \\
\text { izvora }\end{array}$ & $\begin{array}{c}\text { Broj korisničkih } \\
\text { oznaka }\end{array}$ & ISNESS & OFNESS & ABOUTNESS & OSTALO \\
\hline Bosniaca & 10 & 173 & 1 & 138 & 23 & 12 \\
\hline Vjesnik bibliotekara Hrvatske & 10 & 169 & 1 & 143 & 18 & 8 \\
\hline Glasnik Narodne biblioteke Srbije & 10 & 164 & 1 & 143 & 12 & 9 \\
\hline
\end{tabular}


Kao što vidimo iz tabelarnog prikaza, najveći broj korisničkih oznaka časopisa pripada razini ofness, $\mathrm{i}$ to 138 oznake Bosniace (2019) i po 134 oznake Vjesnika bibliotekara Hrvatske (2019) i Glasnika Narodne biblioteke Srbije $(2017,2018)$. Prema tome, izvršena je i analiza korisničkih oznaka na razini ofness (Grafikon 8). Na razini aboutness dodane su 23 korisničke oznake za bh. časopis, 18 oznaka za hrv. te 12 oznaka za srp. časopis; dok je na razini isness za sva tri časopisa dodana po jedna korisnička oznaka budući da se radi o člancima triju časopisa.

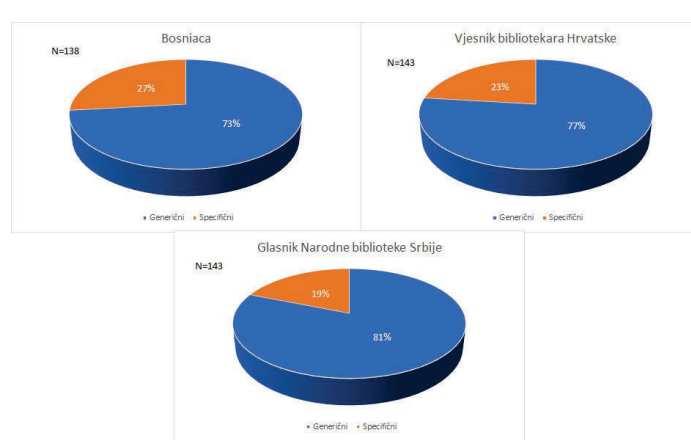

Grafikon 8. Analiza korisničkih oznaka časopisa na razini ofness

Analiza prema razini ofness pokazala je kako je najveći broj korisničkih oznaka dodan na generičkoj razini. Od ukupnog broja 138 ofness korisničkih oznaka za Bosniacu (2019), 73\% oznaka je dodano na generičkoj razini, dok je $27 \%$ dodano na specifičnoj razini. Slična je situacija i s časopisima Vjesnik bibliotekara Hrvatske (2019) i Glasnik Narodne biblioteke Srbije $(2017,2018)$ s po 143 ukupno korisničke oznake, od kojih je 77\% oznaka dodanih na generičkoj razini i 23\% dodanih oznaka na specifičnoj razini za prvi časopis, dok je za drugi časopis udjelno veći broj oznaka od $81 \%$ dodanih na generičkoj razini i udjelno manje od $19 \%$ oznaka dodano na specifičnoj razini.

U konačnici, rezultat analize prema razini značenja korisničkih oznaka za sva tri časopisa pokazao je da su korisničke oznake najviše dodane na generičkoj ofness razini, što je i prihvatljiv i ujedno očekivan rezultat, budući da generički pojmovi ne zahtijevaju predznanje niti specifično znanje već samo prepoznavanje izvora od strane korisnika. Prema tome, značenjskom analizom se odbacuje hipoteza h2: postoji kvalitativna razlika između korisničkih oznaka i ključnih riječi iste građe.

\section{Diskusija}

Summa summarum, rezultati statističke analize pokazali su znatnu kvantitativnu razliku od 79\% korisničkih oznaka naspram kvantitativnom podatku represented are also common nouns in complex expressions in the singular and nominative case, which does not confirm the qualitative differences between the observed bookmarks. On the other hand, the number of added bookmarks indicates the presence of bookmarks that are not present in the subject cataloguing by keywords. Therefore, the presence of new bookmark elements, resulting from assignor users of the same bookmarks, talk a lot about the important role of folksonomies in organizing and searching for information, whereby a hypothesis relating to linguistic analysis h2: there is a qualitative difference between user bookmarks and keywords of the same material, is confirmed

\section{Semantic analysis}

Semantic analysis referred to the content analysis related to the meaning of user bookmarks, which was done with the goal of insight into the quality of the bookmarks that users added to the articles of the journals.

Ivanjko $(2015,128-130)$ for the eponymous analysis uses a model from the authors Klenczoni and Rygiel (2004, 42-61, cited in Ivanjko 2015, 129), which are primarily related to semantic analysis of visual materials, which Ivanjko combined into a table (Figure 2), and which we have adapted for the purposes of this paper to the analysis of journal user bookmarks.

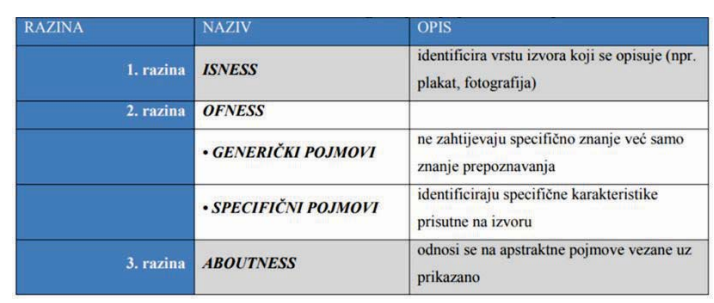

Figure 2. Levels of semantic analysis of user bookmarks (Ivanjko 2015, 130)

First level - isness - identifies the type of source being described, second - ofness - refers to the identification of terms related to a resource, elaborates in more detail the level ofness to generic terms (which do not require specific knowledge but only knowledge of recognition) and specific terms (which identify the specific characteristics present at the source); while the third level - aboutness - refers to abstract terms related to what is shown.

According to the fixed model, the semantic analysis of the levels of article user bookmarks for all three journals that are the subject of this research was performed (Table 1). 
Table 1: Results of the semantic analysis of the journal user bookmark levels

\begin{tabular}{|c|c|c|c|c|c|c|}
\hline $\begin{array}{c}\text { Journal } \\
\text { title }\end{array}$ & $\begin{array}{c}\text { Number of } \\
\text { sources }\end{array}$ & $\begin{array}{c}\text { Number of } \\
\text { user } \\
\text { bookmarks }\end{array}$ & ISNESS & OFNESS & ABOUTNESS & REST \\
\hline Bosniaca & 10 & 173 & 1 & 138 & 23 & 12 \\
\hline Vjesnik bibliotekara Hrvatske & 10 & 169 & 1 & 143 & 18 & 8 \\
\hline Glasnik Narodne biblioteke Srbije & 10 & 164 & 1 & 143 & 12 & 9 \\
\hline
\end{tabular}

od 21\% ključnih riječi, ukupno za sva tri časopisa, što potvrđuje prvu hipotezu statističke analize h1: ključnih riječi će biti manje u odnosu na korisničke oznake. Iz priloženog, ovaj kvantitativni pokazatelj razlike zbog većeg broja dodijeljenih oznaka od strane korisnika predstavlja indikator za primjenu korisničkih oznaka u predmetnoj obradi građe zbog povećanja broja oznaka, tj. baze korpusa oznaka. Kongruentno s tim, kvantitativni indikator primjene korisničkih oznaka u predmetnom opisu građe najviše se ogleda i u iscrpnosti dodanih oznaka od strane korisnika, što potvrđuje i opravdava statistički podatak sumativno za sve časopise provedenog istraživanja o broju dodjeljivanja naspram dodanih oznaka, koje zauzimaju sljedeću relaciju broja dodjeljivanja korisničkih oznaka $73 \%: 27 \%$ dodanih korisničkih oznaka. U ovome slučaju, broj dodjeljivanja pokazuje koherentnost mišljenja korisnika kao subjekata primatelja usluge koji stvaraju kolektivnu inteligenciju dodjeljujući mnoštvo korisničkih oznaka koje su jedinstvene, što potvrđuje ukupan broj dodanih korisničkih oznaka. Na taj način, iste korisničke oznake variranjem od uopćavanja sve do sažimanja oznaka, povećavaju korpusni broj pristupnih tačaka prilikom pretraživanja te samim tim odziv dokumenta biva dosta veći.

Dakako, da postoji indikacija za primjenu korisničkih oznaka u predmetnom opisu građe, detaljnije potvrđuje i niska frekvencija ponavljanja korisničkih oznaka, čime je dokazana i sljedeća hipoteza h2: frekvencija broja dodijeljenih identičnih korisničkih oznaka od strane korisnika dodjeljivača je niska. Ovom dokazanom hipotezom, komplementarno s prvom također potvrđenom hipotezom statističke analize, u konačnici se prihvata prva postavljena hipoteza istraživanja ispitana statističkom analizom h1: postoji kvantitativna razlika između korisničkih oznaka i ključnih riječi iste građe.

Osim toga, važnu ulogu folksonomija u organizaciji i pretraživanju informacija pokazuju i kvalitativni podaci dobijeni lingvističkom analizom koji potvrđuju naznake novih elemenata opisa predmetnom pristupu obrade građe, što ad hoc govori o
As we can see from the table, most journal user bookmarks belong to a level ofness, as follows: 138 bookmarks for Bosniaca (2019) and 134 bookmarks for Vjesnik bibliotekara Hrvatske (Croatian Librarians Herald) (2019) and for Glasnik Narodne biblioteke Srbije (The Herald of the National Library of Serbia) $(2017,2018)$. Therefore, an analysis of user bookmarks at the ofness level was also performed (Chart 8). At the level of aboutness, 23 user bookmarks were added for the BH journal, 18 bookmarks for Croatian and 12 bookmarks for the Serbian journal, while at the isness level, one user bookmark has been added for all three journals, since these are articles from three journals.

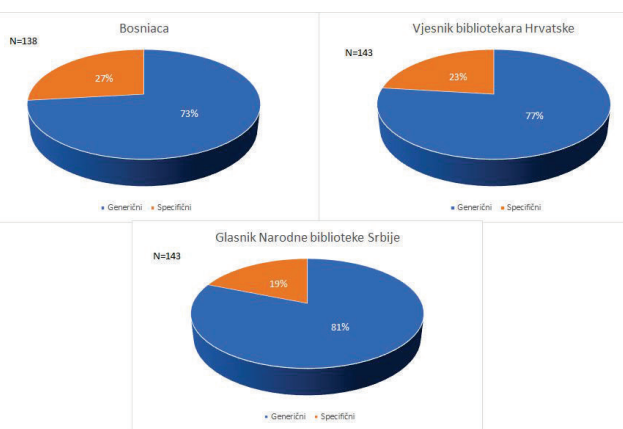

Chart 8. Analysis of journal user bookmarks at the level ofness

Analysis by level ofness showed that the largest number of user bookmarks was added at the generic level. Out of a total of 138 ofness user bookmarks for Bosniaca (2019), 73\% of the bookmarks are added at the generic level, while $27 \%$ was added at a specific level. The situation is similar with journals Vjesnik bibliotekara Hrvatske (Croatian Librarians Herald) (2019) and Glasnik Narodne biblioteke Srbije (The Herald of the National Library of Serbia) $(2017,2018)$ with 143 user bookmarks total, of which $77 \%$ of the bookmarks were added at the generic level and $23 \%$ were added at the specific level for the first journal, while for the second journal the share of more bookmarks than $81 \%$ added at the generic level and a share of less than $19 \%$ of bookmarks added at a specific level.

Finally, the result of the semantic analysis according to the level of user bookmarks for all three journals 
postojanju više indikacija za primjenu korisničkih oznaka u predmetnom opisu građe. Pod naznakama lingvističke analize podrazumijeva se dobijeni broj dodanih oznaka koje pokazuju prisutnost oznaka koje nisu prisutne $\mathrm{u}$ predmetnom pristupu, tj. opisu ključnim riječima, čime se prihvata postavljena hipoteza h2: postoji kvalitativna razlika između korisničkih oznaka i ključnih riječi iste građe, dok se ista hipoteza odbacuje rezultatima značenjske analize, koji pokazuju jednakost korisničkih oznaka ključnim riječima.

Daljnim pregledom korpusa korisničkih oznaka provedenog istraživanja, koherentno s rezultatima istraživanja, evidentno su dokazane i brojne prednosti procesa korisničkog označavanja. Prednosti se ponajviše ogledaju u dodjeljivanju korisničkih oznaka u vidu generičkih pojmova od strane korisnika koji dodjeljuju oznake na osnovu prepoznavanja sadržaja, a ne postojanja specifičnog znanja o predmetnoj građi koju korisnici opisuju. Također, dodjeljivanje vlastitih slobodno izabranih oznaka omogućava korisnicima bolju organizaciju sadržaja, samim tim i bolju pretragu izvora, što će udruženim djelovanjem korisnika koji provode društveno označavanje rezultirati stvaranjem korisničkih zajednica zasnovanih na sistemu kolektivne inteligencije. Sve navedeno, zapravo, očituje elemente potrebe primjene korisničkih oznaka društvenog označavanja u predmetnoj obradi građe.

\section{Zaključak}

$\mathrm{Na}$ osnovu analize ustanovljeno je da društveno označavanje može doprinijeti i olakšanom pristupu građi u predmetnom katalogu kroz unapređenje predmetnih odrednica korisničkim oznakama dodijeljenim jezikom korisnika putem alata za društveno označavanje. Sve je to potvrđeno istraživanjem putem Diigo alata za društveno označavanje kroz komparativnu analizu ključnih riječi i korisničkih oznaka članaka časopisa Vjesnik bibliotekara $\mathrm{Hr}$ vatske (2019), Glasnik Narodne biblioteke Srbije $(2017,2018)$ i Bosniaca (2019). Kvalitativna analiza je pokazala da nema značajnih razlika između korisničkih oznaka i ključnih riječi, dok je kvantitativna analiza pokazala značajno veći broj korisničkih oznaka naspram ključnih riječi. Veliki broj oznaka dodijeljenih od strane korisnika povećava pristupne tačke u pronalasku sadržaja. Ujedno, oznake dodane jezikom korisnika rješavaju problem verbalnog pristupa sadržaju koji je u bibliotečkom katalogu oduvijek bio problem. Sve ovo predstavlja indikaciju za primjenu korisničkih oznaka u predmetnom opisu kako u tradicionalnom predmetnom showed that user bookmarks were mostly added at the generic ofness level, which is both an acceptable and at the same time an expected result, since generic terms do not require prior knowledge or specific knowledge but only source recognition by the user. Therefore, semantic analysis of hypotheses $\mathrm{h} 2$ : there is a qualitative difference between user bookmarks and keywords of the same material, is dismissed.

\section{Discussion}

Summa summarum, the results of the statistical analysis showed a significant quantitative difference of $79 \%$ of user bookmarks compared to the quantitative data of $21 \%$ keywords, total for all three journals, which confirms the first hypothesis of statistical analysis h1: keywords will be less than user bookmarks. From the stated, this quantitative indicator of the difference due to the higher number of bookmarks assigned by the user, represents the indicator for the application of user bookmarks in the subject cataloguing material due to the increase in the number of bookmarks, i.e. the corpus base of bookmarks. Congruently with this, a quantitative indicator of the use of user bookmarks in the subject cataloguing of material, is mostly reflected in the exhaustiveness of the bookmarks added by the user, which confirms and justifies the statistics summatively for all journals of the conducted research on the number of assignments versus added bookmarks, which take the following relation of the number of assignment of user bookmarks $73 \%: 27 \%$ of added user bookmarks. In this case, the number of assignments shows the coherence of the opinion of users as entities of the recipient of the service that create collective intelligence by assigning a multitude of user bookmarks that are unique, which confirms the total number of added user bookmarks. In that way, the same user bookmarks by varying from generalizations to bookmark compressing, increase the corpus number of access points when searching, and thus the response of the document is much higher.

Of course, there is an indication for the use of user bookmarks in the subject cataloguing of material, the low frequency of user bookmarking recurrence is also confirmed in more detail, whereby the hypothesis h2: the frequency of the number of identical user bookmarks assigned by the assignor user is low, is also proved. With this proven hypothesis, complementary to the first also confirmed hypothesis of statistical analysis, ultimately, the first established research hypothesis $\mathrm{h} 1$ : there is a quantitative difference between user bookmarks and keywords of the same material, examined by statistical analysis, is accepted. 
katalogu tako i u elektronskom katalogu na internetskim bibliografskim sistemima i uslugama. U vezi s tim, važno je naglasiti da korisničke oznake i ključne riječi dodijeljene od strane korisnika / predmetne odrednice imaju istu namjenu koja se očituje $u$ organizaciji informacija, te $u$ okviru toga korisničke oznake ne mogu zamijeniti predmetne odrednice kao sistem predmetnog označavanja, već one jedinstvenim djelovanjem mogu unaprijediti organizaciju i pristup informacijama u katalogu, što je i potvrđeno provedenim istraživanjem.
In addition, the important role of folksonomy in the organization and search of information is shown by qualitative data obtained by linguistic analysis, which confirm the indications of new description elements of subject approach to material cataloguing, which ad hoc suggests the existence of multiple indications for the use of user bookmarks in the subject cataloguing of material. Under the indications of linguistic analysis, the resulting number of added bookmarks, which indicate the presence of bookmarks that are not present in the subject approach, is assumed, i.e. cataloguing by keywords, whereby established hypothesis $\mathrm{h} 2$ : there is a qualitative difference between user bookmarks and keywords of the same material, is being accepted, while the same hypothesis is rejected by the results of the semantic analysis, which show the equality of user bookmarks by keywords.

Further review of the corpus of user bookmarks of the conducted research, coherent with the research results, numerous advantages of the user bookmark process, have been evidently proven. The advantages are mostly reflected in the assignment of user bookmarks in the form of generic terms by users who assign bookmarks based on content recognition, and not the existence of specific knowledge about the subject material that users describe. Also, assigning their own freely chosen bookmarks allows users to better organize their content, hence a better search of sources, and which, through the joint action of users who implement social bookmarking, will result in the creation of user communities based on a system of collective intelligence. All of the above, in fact, manifests the elements of the need to use user bookmarks of social bookmarking in the subject cataloguing of the material.

\section{Conclusion}

Based on analysis, it has been established that social bookmarking can also contribute to easier access to the material in the subject catalogue through the improvement of the subject headings with user bookmarks, assigned user language via the social bookmarking tool. All this was confirmed by research through the Diigo tool for social bookmarking through a comparative analysis of keywords and user bookmarks of journal articles of Vjesnik bibliotekara Hrvatske (Croatian Librarians Herald) (2019), Glasnik Narodne biblioteke Srbije (The Herald of the National Library of Serbia) (2017, 2018) and Bosniaca (2019). Qualitative analysis has shown that there are no significant differences between user bookmarks and keywords, while quantitative analysis showed a significantly 
higher number of user bookmarks versus keywords. A large number of bookmarks assigned by users are increasing access points in the content finding. At the same time, bookmarks added in the users language solve the problem of verbal access to content, which has always been a problem in the library catalogue. All this is an indication for the use of user bookmarks in the subject cataloguing both in the traditional subject catalogue and in the electronic catalogue on online bibliographic systems and services. In this matter, it is important to emphasize that user bookmarks and keywords assigned by

\section{Literatura / Bibliography}

- Bosniaca: časopis Nacionalne i univerzitetske biblioteke Bosne i Hercegovine 28 (28) 2019. Sarajevo: Nacionalna i univerzitetska biblioteka Bosne i Hercegovine. http://bosniaca.nub.ba/index.php/bosniaca/ article/view/447/456. Datum pristupa 25. 9. 2020.

- Diigo "Folksonomija". https://groups.diigo.com/group/folksonomija. Datum pristupa: 25. 9. 2020.

- Dizdar, Senada. 2011. Od podataka do metapodatka. Sarajevo: Nacionalna i univerzitetska biblioteka Bosne i Hercegovine.

- Glasnik Narodne biblioteke Srbije 16 (19) 2017; 17 (20) 2018. ISSN 1450-8915. Beograd: Narodna biblioteka Srbije. https://www.nb.rs/view_file.php?file_ $\mathrm{id}=5587$; https://www.nb.rs/publications/publication. php?id=34242. Datum pristupa: 25. 9. 2020.

- Golder, Scott A., i Bernando Huberman. 2006. "Usage patterns of collaborative tagging systems" Journal of information science 32 (2): 198-208. DOI: https://doi. org/10.1177/0165551506062337. Datum pristupa 25. 9. 2020 .

- Heckner, M., S. Mühlbacher, i Christian Wolff. 2008. Tagging tagging: analysing user keywords in scientific bibliography management systems. Arizona: The University of Arizona. https://repository.arizona.edu/ bitstream/handle/10150/105484/tagging_tagging_ NKOS_07.pdf?sequence $=1 \&$ isAllowed $=y$. Datum pristupa 25. 9. 2020.

- Ivanjko, Tomislav. 2015. "Pristup analizi i primjeni korisničkog označivanja u predmetnom opisu baštinske građe" PhD diss., Filozofski fakultet Sveučilišta u Zagrebu.

- Klenczon, Wanda, i Pawel Rygiel. 2004. "Librarian cornered by images, or how to index visual resources" Cataloging and Classification Quarterly 52 (1): 42-61. DOI: https://doi.org/10.1080/01639374.2013. 848123. Datum pristupa 25. 9. 2020. users / subject headings have the same purpose that manifests in the organization of information, and within that, user bookmarks cannot replace the subject headings as a subject indexing system, but they can improve the organization and access to information in the catalogue through a single action, which is confirmed by the implemented research.

- Lohmann, Steffen. 2013. "Conceptualization and visualization of tagging and folksonomies" $\mathrm{PhD}$ diss., Universität Duisburg-Essen. https://pdfs.semanticscholar. org/f094/c4aadfe1bab4b2f6eb813e7539955905016d. pdf?_ga=2.225486876.706666945.1585216108996640791.1582916010. Datum pristupa 25. 9. 2020.

- Mikačić, Mira. 1996. Teorijske osnove sustava za predmetno označavanje. Zagreb: Hrvatsko bibliotekarsko društvo.

- Shirky, Clay. 2005. "A group is its own worst enemy" U The Best Software Writing I. Apress, 183-209. New York: Springer Publishing. https://doi. org/10.1007/978-1-4302-0038-3_23. Datum pristupa 25. 9. 2020.

- Špiranec, Sonja, i Tomislav Ivanjko. 2012. "Predmetni jezici s korisničkim jamstvom: što možemo naučiti od folksonomija?" U 15. seminar Arhivi, knjižnice, muzeji: mogućnosti suradnje u okruženju globalne informacijske infrastrukture, 68. Zagreb: Hrvatsko knjižničarsko društvo. file://C:/Users/Korisnik/ Downloads/618936.AKM2011_piranec_Ivanjko_ Predmetni_jezici_s_korisnikim_jamstvom_preprint. pdf. Datum pristupa: 25. 9. 2020.

- Trant, Jennifer. 2009. "Tagging, folksonomy and art museums: Early Experiments and Ongoing Research" Journal of Digital Information 10 (1): 1-50. https:// pdfs.semanticscholar.org/dd27/4697c862d43b6495 3c62417920a0165d411a.pdf. Datum pristupa 25. 9. 2020.

- Vander Wal, Thomas. 2007. "Folksonomy: Folksonomy coinage and definition" Vanderwal.net. http:// vanderwal.net/folksonomy.html. Datum pristupa 25. 9. 2020.

- Vjesnik bibliotekara Hrvatske 62, (2) 2019. ISSN 1334-6938. Zagreb: Hrvatsko knjižničarsko društvo. https://www.hkdrustvo.hr/vjesnik-bibliotekara-hrvatske/index.php/vbh/issue/view/31. Datum pristupa 25. 9. 2020 . 